\title{
BIDIRECTIONAL APPROACH FOR UNIVERSITY MANAGEMENT: IMPROVED RELATIONSHIP WITH STUDENTS AND EDUCATIONAL COSTS MANAGEMENT
}

\author{
Nicoleta Valentina FLOREA (D) 1 , Liliana PASCHIA (D)2, Dan Marius COMAN(D)1, \\ Constantin Aurelian IONESCU (D) ${ }^{*}$, Mihaela Denisa COMAN (D) 3 , \\ Corina Maria ENE (D)2, Nicoleta Luminita GUDANESCU NICOLAU (D) 4,2 \\ ${ }^{1}$ Faculty of Economic Sciences, Valahia University of Targoviste, Targoviste, Romania \\ ${ }^{2}$ Faculty of Economics, Hyperion University of Bucharest, Bucharest, Romania \\ ${ }^{3}$ Institute of Multidisciplinary Research for Science and Technology of \\ Valahia University of Targoviste, Targoviste, Romania \\ ${ }^{4}$ Institute of National Economy, Romanian Academy, Bucharest, Romania
}

Received 29 April 2020; accepted 26 February 2021

\begin{abstract}
The research, through a bidirectional approach, aims to develop the university management of the degree programs in order to attract and maintain the potential students, as well as to estimate and manage the costs of the educational services offered during their life cycle. The authors bring into the centre of the study the importance of the simulation process in predicting a possible future and reduce the probable risks and costs from time. The results confirm that the simulation methods used help the universities to determine the future risks and to predict when and what relationship marketing programs to use in order to attract, maintain and grow the number of valuable students and also to ensure cost-effective management of university programs.
\end{abstract}

Keywords: university management, Monte Carlo simulation, Markov chains, Gauss distribution, stochastic simulation, life-cycle cost method (LCC).

JEL Classification: I20, I29, M41.

Online supplementary material: Supporting information for this paper is available as online supplementary material at https://doi.org/10.3846/jbem.2021.14687

\section{Introduction}

In the current period, many specific factors have occurred at the level of university education (demography, technical and technological discoveries, knowledge-based information society, artificial intelligence, data analytics, and block chain technology), which have completely

*Corresponding author. E-mail: ionescuaurelian89@gmail.com

Copyright $\odot 2021$ The Author(s). Published by Vilnius Gediminas Technical University

This is an Open Access article distributed under the terms of the Creative Commons Attribution License (http://creativecommons. org/licenses/by/4.0/), which permits unrestricted use, distribution, and reproduction in any medium, provided the original author and source are credited. 
transformed the structure and functionality of universities (Balzer, 2020; Chaminade \& Lundvall, 2019; Kolomytseva \& Pavlovska, 2020; Williams, 2019). The contemporary trend is for universities to be governed by the labour market, and their orientation is towards final consumers (economic entities, state institutions, who will benefit from skilled labour) (Altbach et al., 2009; Evans \& Gill, 2017; Reichert, 2019). Knowing that relationships for human beings are essential, institutions, including universities, must understand that building a strategy on marketing relationships will lead to competitive advantage and satisfying students (Palmatier \& Steinhoff, 2019; Toma, 2011). Universities, establishing their standards, creating new levels of excellent standards, are offering learning, education, and research (Kahn \& Anderson, 2019). Now they are autonomous and ask from the pleasant student thinking, learning as understanding in a different way (Dall'Alba \& Barnacle, 2007), due to their open-access mission (Schneider \& Deane, 2015) and healthy attitudes, in order to face the economic, social, cultural, political, and technological challenges existing in the work market. Universities are increasingly taking inspiration from the business world in an attempt to achieve profitability in a competitive market. Universities are required to make realistic and valid estimates to ensure the essential sources of funding, and the costs involved must ensure both the supportability of the different categories of beneficiaries and the prosperity at the institution. That increasingly arises the need for evaluation, information, and communication on the cost of education in higher education (Ianos, 2010).

The study aims to develop the university management of undergraduate programs through an innovative two-way approach, on the one hand from the perspective of attracting and maintaining potential students and identifying optimal solutions for development, and on the other hand the estimation and management of the costs of educational services offered during their life cycle. Thus, the purpose of the research is to predict the future number of students enrolled, based on data from previous years and to estimate and manage the costs of educational services during their life cycle.

The objectives of the study are: Objective 1 - predict future problems in attracting and maintaining students and future solutions for developing the number of students; predict the right number of enrolled student in order to ensure effectiveness for the analyzed institution, observe the difference between the obtained calculation and the real data; improving the relationship with future students, getting in-value for students and the institution; Objective 2 - application of the life-cycle cost method (LCC) of an educational license program belonging to the economic profile, in order to identify whether the results of the LCC method add value to accounting information on the relevance of costs or the composition of the cost of production or provision of the service. Starting from the announced objectives, the research hypotheses are: Hypothesis 1: Statistical and econometric methods contribute to predicting future problems in attracting, enrolling and retaining students to improve the relationship students-university; Hypothesis 2: LCC and statistical methods applied for an educational license program belonging to the economic profile add value to accounting information on the relevance of costs or the composition of the cost of production or provision of the service. The novelty of the paper lies in the fact that it addresses a current problem with practical implications, which involves presenting a model in which statistical and econometric methods and the specific method of management accounting (LCC) are used as a bidirectional 
approach to improve university management. The structure of the research presents the main studies from the scientific literature, the applied materials and methods, followed by the results and conclusions of the research.

\section{Literature review}

Evans and Gill (2017) ask themselves if the university is a business, and they also answer, by providing the following information: that between the student and the institution is made a contract- students are obligated to attend the courses and the seminars, to pass the exams and to pay their fees, and the institution, through its professors, is obligated to offer excellent quality teaching, adequate facilities and well-designed courses, meaning education and academic excellence (Nejati, 2013; Sultan \& Wong, 2019). The universities are using relationship marketing by increasing students' involvement in university activities, such as technologybased activities, programs based on the relationship students- librarians (Brock, 2019; Kaur, 2009; Pringle \& Fritz, 2019). According to Baran et al. (2008), there are three levels of relational marketing. Level 1 is based on offering discounts in order to attract and maintain students, prices, money scholarships for good results, study scholarships for the same good results, reduction for student camps, travel, and transportation. Level 2 is based on user customization and social connections as special events for students: parties (just for students, for students and the professor, such as Christmas, seminars, conferences, workshops, focus groups, educational programs, PR events, sports activities, alumni relationships, counselling and assistance, counselling in career, social events (Christmas events, PR campaigns for children and families with lower income, international sessions for students, concerts, and programs for the beginning of the year, associations). Level 3 is based on connections sustained by structural solutions, as computers and IT programs in order to detect the students' payments, the preferences for some courses, the amount of money and the moment of paying the preference or for a program, or the frequency and the recency of presence, or the average calcification per semester or year, the evidence of results. These relationships allow the university to be known using recommendation and word-of-mouth (Oplatka \& Hemsley-Brown, 2012), alumni relations (Ong, 2009), which represents acquisition and retention strategies for universities and a new approach for CRM, academic counselling and assistance, and new technology forming a new generation of students (Harland, 2012). Relationships are the way to gain new knowledge and experience and to confront different barriers (Sheldon \& Turner-Vorbeck, 2019).

Students are regarded as customers, to whom the universities are offering them education services, and because the clients have rights for what they are paying for, they may have complaints. However, also, the university has rights, because the contract is for the two parts (Evans \& Gill, 2017). Relational marketing is perceived as a bond of equality between partners (Baran et al., 2008), and the partnership between the university and its students is characterized by trust, commitment, communication, collaboration, and knowledge sharing, resulted through the mutual satisfaction of objectives. The relationship with students is different according to the stage of student life-cycle: recruitment stage, enrolment, retention, and post-graduation (Ackerman \& Schibrowsky, 2007; Lechtchinskaia et al., 2012; Perna \& 
Baraldi, 2014). Relations with students, perceived as the relations with customers, may conduct to collecting information for a database, which may become strategic knowledge and may be used in order to increase the ability of the institution to sell its educational services more efficient, to create at the highest level of satisfaction and loyalty with obtaining a high profit (Linger et al., 2004). Thus, the students-based orientation, become a 1-to-1 relation, based on creating and offering added-value; this type of relationship developed due to new technologies (Svend \& Oliver, 2019) and is belonging to those organizations which are using data from the past about its customers and are used in order to predict what client wants. Thus, the organization will treat its customers differently and will grow the mutual value (Chen \& Popovich, 2003; Foglieni et al., 2017; Fukuda, 2017; Lamb et al., 2012; Peppers \& Rogers, 2004; Sauro, 2015; Valdani \& Arbore, 2013; Winer, 2001).

\section{Materials and methods}

Objective 1 - The used tools are descriptive statistics, Monte Carlo simulation, Markov chains, Gauss distribution, and informatics programs (Excel and MATLAB). The institution which has been analysed is a university from Romania, denoted from strategic reasons, as UR. On the 17th days for the students' enrolment (the summer period), were extracted data for four years between 2016-2019. The total number of enrolled students is shown in the table below (Table 1).

Table 1. Number of enrolled students between 2016-2019

\begin{tabular}{|c|c|c|c|c|}
\hline Day/Year & 2019 & 2018 & 2017 & 2016 \\
\hline 1 & 0 & 4 & 0 & 0 \\
\hline 2 & 1 & 4 & 3 & 0 \\
\hline 3 & 1 & 4 & 6 & 7 \\
\hline 4 & 2 & 6 & 7 & 8 \\
\hline 5 & 3 & 7 & 7 & 10 \\
\hline 6 & 3 & 7 & 10 & 10 \\
\hline 7 & 5 & 8 & 10 & 10 \\
\hline 8 & 7 & 8 & 12 & 11 \\
\hline 9 & 9 & 9 & 13 & 13 \\
\hline 10 & 12 & 11 & 13 & 14 \\
\hline 11 & 12 & 11 & 14 & 14 \\
\hline 12 & 14 & 13 & 14 & 16 \\
\hline 13 & 18 & 13 & 14 & 19 \\
\hline 14 & 20 & 15 & 15 & 27 \\
\hline 15 & 23 & 16 & 17 & 189 \\
\hline 16 & 24 & 17 & 17 & 22 \\
\hline 17 & 24 & 18 & 194 & \\
\hline Total & 178 & 171 & & \\
\hline
\end{tabular}


Monte Carlo method is used in different economic activities, so using it in the education field is a novelty. Monte Carlo method is demonstrating its efficiency in analysing phenomenon characterized by a large number of variables and parameters (Duica \& Florea, 2018; Zio, 2013). Markov chains are a mathematical method used in planning and forecasting (Beardwell \& Claydon, 2007; Ching et al., 2013; Duica et al., 2019; Florea \& Mihai, 2017; Nastase (Bidireanu) et al., 2019; Tracey, 2004), in this case, it is analysed the forecasting of the enrolled student evolution.

Objective 2 - The first variant of analysis of the results obtained by applying the model specific to the LCC method is the sensitivity analysis. The analysis can be repeated for each parameter of the model or only for parameters considered to have a significant impact on the results. Useful in one-way sensitivity analysis is the choice of the values of the smallest and highest of the parameters chosen to be analysed. The choice of these parameters was determined by their uncertainty or their dependence on factors that are not related to the incidence of decision-makers (population dynamics, the degree of promotion of students in the previous cycle, or market dynamics work). For the application of the LCC method and the sensitivity analysis was prepared Table 2, which shows the costs related to the introduction of a license program.

According to Brown and Yanuck (1980), the LCC method is used when it is necessary to draw up a decision related to the purchase of an asset that requires substantial maintenance and which induces considerable operational costs over its life (Brown \& Yanuck, 1980). Dhillon (2009) considers that the primary usage of the LCC method lies in the possibility of comparing competitive projects, long-term planning, and providing support to budgeting and control processes, selecting the best bid or elaboration of decisions on replacement of equipment (Dhillon, 2009). More recent approaches regard the LCC method as a useful engineering tool that can be used in the design phase and when product or service development purchases are made, as well as as an instrument that can be applied in a pro-active manner in management and management accounting, as well as in the management of environmental issues (Asiedu \& Gu, 1998; Ashworth, 1993; Emblemsvåg, 2003; Gluch \& Baumann, 2004; Karim, 2006; Spickova \& Myskova, 2015).

Table 2. Costs related to the introduction of a licensing program

\begin{tabular}{|c|c|c|c|c|c|c|c|}
\hline Activities & $\begin{array}{l}\text { Dura- } \\
\text { tion }\end{array}$ & Costs involved & Year 1 & Year 2 & Year 3 & Year 4 & Year 5 \\
\hline \multicolumn{8}{|c|}{ Research and development costs (Eur) } \\
\hline \multirow{2}{*}{$\begin{array}{l}\text { Program } \\
\text { planning }\end{array}$} & \multirow[t]{2}{*}{1 Week } & $\begin{array}{l}\text { direct salaries (program } \\
\text { manager, secretary) }\end{array}$ & 202 & - & - & - & - \\
\hline & & indirect overhead costs & 21 & - & - & - & - \\
\hline \multirow{4}{*}{$\begin{array}{l}\text { Design and } \\
\text { planning }\end{array}$} & \multirow{4}{*}{2 Weeks } & direct salaries & 213 & - & - & - & - \\
\hline & & $\begin{array}{l}\text { costs related to the materials } \\
\text { used }\end{array}$ & 64 & - & - & - & - \\
\hline & & $\begin{array}{l}\text { costs of documentation and } \\
\text { market study }\end{array}$ & 170 & - & - & - & - \\
\hline & & indirect overhead costs & 43 & - & - & - & - \\
\hline
\end{tabular}


Continued Table 2

\begin{tabular}{|c|c|c|c|c|c|c|c|}
\hline Activities & $\begin{array}{l}\text { Dura- } \\
\text { tion }\end{array}$ & Costs involved & Year 1 & Year 2 & Year 3 & Year 4 & Year 5 \\
\hline \multirow{4}{*}{$\begin{array}{l}\text { Design and } \\
\text { engineering } \\
\text { of the service }\end{array}$} & \multirow{4}{*}{4 Weeks } & direct salaries & 426 & - & - & - & - \\
\hline & & designing a web page & 532 & - & - & - & - \\
\hline & & marketing and promotion costs & 1,064 & - & - & - & - \\
\hline & & indirect overhead costs & 85 & - & - & - & - \\
\hline \multirow{2}{*}{$\begin{array}{l}\text { Lifecycle } \\
\text { management }\end{array}$} & \multirow{2}{*}{5 Weeks } & direct salaries & 1,053 & 1,053 & 1,053 & 1,053 & 1,053 \\
\hline & & indirect overhead costs & 255 & 266 & 279 & 287 & 293 \\
\hline \multirow{3}{*}{$\begin{array}{l}\text { Testing and } \\
\text { evaluating } \\
\text { the service }\end{array}$} & \multirow{3}{*}{$\begin{array}{l}\text { One } \\
\text { year }\end{array}$} & direct salaries & 1,053 & - & - & - & - \\
\hline & & $\begin{array}{l}\text { costs related to performance } \\
\text { monitoring }\end{array}$ & 255 & - & - & - & - \\
\hline & & indirect costs & 11 & - & - & - & - \\
\hline \multirow{2}{*}{$\begin{array}{l}\text { Service } \\
\text { market } \\
\text { research }\end{array}$} & \multirow{2}{*}{4 Weeks } & direct salaries & 223 & - & - & - & - \\
\hline & & overhead costs & 101 & - & - & - & - \\
\hline \multicolumn{3}{|c|}{ Total research and development costs } & 5,771 & 1,319 & 1,332 & 1,340 & 1,346 \\
\hline \multicolumn{8}{|c|}{ Service costs (Eur) } \\
\hline \multirow{3}{*}{$\begin{array}{l}\text { Operational } \\
\text { costs }\end{array}$} & \multirow{3}{*}{$\begin{array}{l}\text { Five } \\
\text { years }\end{array}$} & $\begin{array}{l}\text { personal salaries involved } \\
\text { in the authorization of the } \\
\text { program }\end{array}$ & 426 & 213 & 213 & 213 & 213 \\
\hline & & material costs & 106 & 85 & 745 & 426 & 106 \\
\hline & & $\begin{array}{l}\text { costs of authorizing the } \\
\text { program }\end{array}$ & 213 & - & - & 213 & - \\
\hline $\begin{array}{l}\text { Quality } \\
\text { control }\end{array}$ & \begin{tabular}{|l|} 
Five \\
years
\end{tabular} & $\begin{array}{l}\text { costs related to the program } \\
\text { director }\end{array}$ & 426 & 426 & 426 & 426 & 426 \\
\hline $\begin{array}{l}\text { Initial logistic } \\
\text { support }\end{array}$ & $\begin{array}{l}\text { One } \\
\text { year }\end{array}$ & $\begin{array}{l}\text { logistical costs of providing the } \\
\text { program }\end{array}$ & 362 & - & - & - & - \\
\hline $\begin{array}{l}\text { Operational } \\
\text { analysis }\end{array}$ & \begin{tabular}{|l} 
Five \\
years
\end{tabular} & operational analysis costs & 277 & 255 & 234 & 213 & 106 \\
\hline \multicolumn{3}{|c|}{ Total service costs } & 1,809 & 979 & 1,617 & 1,489 & 851 \\
\hline \multicolumn{8}{|c|}{ Operational and support costs (Eur) } \\
\hline Service costs & \begin{tabular}{|l|} 
Five \\
years
\end{tabular} & $\begin{array}{l}\text { costs associated with teachers' } \\
\text { salaries }\end{array}$ & 49,660 & 49,660 & 49,660 & 49,660 & 49,660 \\
\hline $\begin{array}{l}\text { Distribution } \\
\text { costs }\end{array}$ & \begin{tabular}{|l|} 
Five \\
years
\end{tabular} & marketing costs & 851 & 851 & 638 & 426 & - \\
\hline $\begin{array}{l}\text { Costs related } \\
\text { to logistic } \\
\text { support }\end{array}$ & $\begin{array}{l}\text { Five } \\
\text { years }\end{array}$ & logistic costs & 1,277 & 1,170 & 1,064 & 851 & 426 \\
\hline \multicolumn{3}{|c|}{ Total operating and support costs } & 51,787 & 51,681 & 51,362 & 50,936 & 50,085 \\
\hline \multicolumn{8}{|c|}{ Withdrawal costs (Eur) } \\
\hline $\begin{array}{l}\text { Final } \\
\text { withdrawal } \\
\text { costs }\end{array}$ & $\begin{array}{l}\text { One } \\
\text { year }\end{array}$ & & - & - & - & - & 426 \\
\hline
\end{tabular}


End of Table 2

\begin{tabular}{|l|l|c|c|c|c|c|c|}
\hline Activities & $\begin{array}{c}\text { Dura- } \\
\text { tion }\end{array}$ & Costs involved & Year 1 & Year 2 & Year 3 & Year 4 & Year 5 \\
\hline Removal cost & $\begin{array}{l}\text { One } \\
\text { year }\end{array}$ & & - & - & - & - & 309 \\
\hline Final value & $\begin{array}{l}\text { One } \\
\text { year }\end{array}$ & - & - & - & - & 4,787 \\
\hline Total withdrawal costs & - & - & - & - & 5,521 \\
\hline LCC - annual (Eur) & 59,367 & 53,978 & 54,311 & 53,766 & 57,803 \\
\hline LCC Total costs (5 years) (Eur) \\
\hline
\end{tabular}

\section{Results}

\subsection{Results for Objective 1}

Making a summary of the descriptive statistics, using the data in Table 1, the following results are obtained and presented in Table 3.

Table 3. The summary of the descriptive statistics of analysed data on years

\begin{tabular}{|l|c|c|c|c|}
\hline & 2019 & 2018 & 2017 & 2016 \\
\hline Mean & 10.47058824 & 10.05882 & 11.41176 & 11.11765 \\
\hline Standard Error & 2.104123485 & 1.126129 & 1.336861 & 1.646928 \\
\hline Median & 9 & 9 & 13 & 11 \\
\hline Mode & 1 & 4 & 14 & 10 \\
\hline Standard Deviation & 8.675523378 & 4.643148 & 5.512019 & 6.790456 \\
\hline Sample Variance & 75.26470588 & 21.55882 & 30.38235 & 46.11029 \\
\hline Kurtosis & -1.34507682 & -1.14557 & 0.13355 & 0.896127 \\
\hline Skewness & 0.408550837 & 0.288797 & -0.32767 & 0.253731 \\
\hline Range & 24 & 14 & 22 & 27 \\
\hline Minimum & 0 & 4 & 0 & 0 \\
\hline Maximum & 24 & 18 & 22 & 27 \\
\hline Sum & 178 & 171 & 194 & 189 \\
\hline Count & 17 & 17 & 17 & 17 \\
\hline Confidence Level (99.0\%) & 6.146 & 3.289 & 3.905 & 4.81 \\
\hline
\end{tabular}

The smallest mean from the four series of data is for 2018, and the biggest is 11.41 for 2017, and the median is between 9 and 13. The mode is between 1 (2019) and 13 (for 2017). The minimum for this series of data is 0 (for three series), and 4 (for 2018), and the maximum is 27 (for 2016), 24 (for 2019), 22 (for 2017), and 18 (for (2018). The range for the difference between the maximum value and the minimum value is the biggest for 2016 (27), 
and the smallest is for 2018 (14). The sample variance is between 21.56 (for 2018) and 75.26 (for 2019), and the standard deviation is between 4.643 (for 2018) and 8.676 (for 2019), having small values for all the variables. Therefore, it can be considered that the series is relatively homogeneous. The standard error is between 1.126 and 2.104. Skewness has negative value only for 2017 (-0.33), the series being negatively asymmetric, but weakly, the curve is in the left. For the other three series of data, the skewness is positive between 0.254 and 0.409 , meaning that for 2017 the series of data is skewed to the left, and for other three are skewed to the right. The kurtosis is negative for 2019, and 2018, but for 2017 and 2016 is positive ( 0.134 and 0.896), being much below the benchmark for a normal distribution of 3 , which is positioned near normality, meaning that the curve is not so sharpened, having a platykurtic curve.

\subsubsection{Monte Carlo simulation}

In order to simulate the future number of enrolled students, it will be determined the daily probability using relative frequency (Table 4).

Table 4. Data regarding the enrolled students and the probability of enrolment

\begin{tabular}{|c|c|c|c|c|}
\hline $\begin{array}{c}\text { No. of } \\
\text { enrolment }\left(X_{i}\right)\end{array}$ & $\begin{array}{c}\text { No. of cases } \\
\left(f_{i}\right)\end{array}$ & Prob. $\left(P_{x i}\right)$ & $\begin{array}{c}\text { Cumulated prob. } \\
\left(F\left(x_{i}\right)\right)\end{array}$ & $\begin{array}{c}\text { Intervals } \\
\left(F\left(x_{i}-1\right), F\left(x_{i}\right)\right)\end{array}$ \\
\hline 0 & 1 & 0 & 0 & \\
\hline 1 & 2 & 0.01 & 0.01 & $0-0.01$ \\
\hline 2 & 1 & 0.01 & 0.02 & $0.01-0.02$ \\
\hline 3 & 2 & 0.03 & 0.06 & $0.02-0.06$ \\
\hline 5 & 1 & 0.03 & 0.08 & $0.06-0.08$ \\
\hline 7 & 1 & 0.04 & 0.12 & $0.08-0.12$ \\
\hline 9 & 1 & 0.05 & 0.17 & $0.12-0.17$ \\
\hline 12 & 2 & 0.13 & 0.31 & $0.17-0.31$ \\
\hline 14 & 1 & 0.08 & 0.39 & $0.31-0.39$ \\
\hline 18 & 1 & 0.10 & 0.49 & $0.39-0.49$ \\
\hline 20 & 1 & 0.11 & 0.60 & $0.49-0.60$ \\
\hline 23 & 1 & 0.13 & 0.73 & $0.60-0.73$ \\
\hline 24 & 2 & 0.27 & 1.00 & $0.73-1.00$ \\
\hline & $\mathrm{N}$ & 1 & & \\
\hline
\end{tabular}

Using the Monte Carlo method involves applying the following procedure (Luban, 2005): in step 1, are determined the probabilities $P\left(X=x_{i}\right)=P\left(x_{i}\right)$ and the cumulative distribution function $F\left(x_{i}\right)=P\left(X \leq x_{i}\right)=\Sigma P(v)$, for $x_{i} \in\left\{x_{1}, x_{2}, \ldots, x_{m}\right\}$; in step 2, there are associated intervals of random numbers for each discrete variable (graphically, $F(x)$ has the form of a step, its height being equal to the probability $P\left(x_{i}\right)$, and the interval of random number associated with the value $x_{i}$ as Figure 1$)$. To each value xi is associated the interval $\left(F\left(x_{i}-1\right), F\left(x_{i}\right)\right)$ with $F\left(x_{0}\right)=0$ (Table 5); in step 3 , it is generated a random number u uniformly reported in the interval $(0,1)$ using a generator (Table 5); in step 4 , the same procedure is made as in the step 3 until it is obtained the desired simulated selection. 

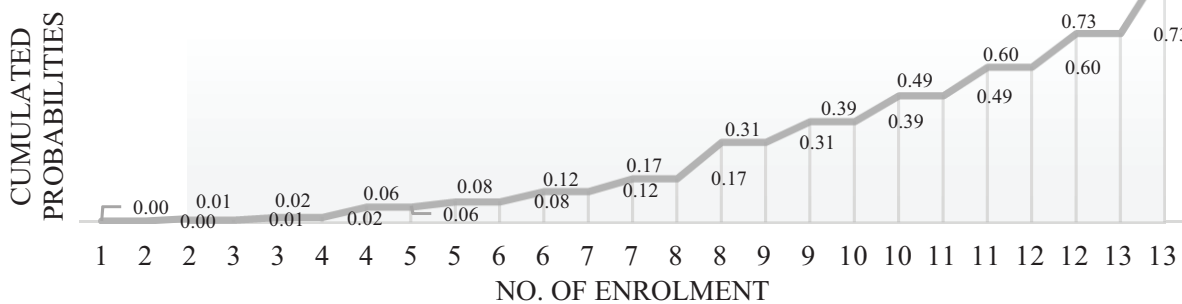

Figure 1. Generating a value xi of discrete probabilistic variable

Table 5. Generating random number $u$

\begin{tabular}{|c|c|c|c|c|}
\hline No. & Random number $u$ & $\begin{array}{c}\text { Number of } \\
\text { candidates registered } \\
\text { according to the } \\
\text { interval }\end{array}$ & $\left(x_{i}-x_{m e d}\right)$ & $\left(x_{i}-x_{m e d}\right)^{2}$ \\
\hline 1 & 0.3687 & 14 & -4.95 & 24.5025 \\
\hline 2 & 0.2405 & 12 & -6.95 & 48.3025 \\
\hline 3 & 0.6786 & 23 & 4.05 & 16.4025 \\
\hline 4 & 0.6865 & 23 & 4.05 & 16.4025 \\
\hline 5 & 0.6071 & 23 & 4.05 & 16.4025 \\
\hline 6 & 0.4474 & 18 & -0.95 & 0.9025 \\
\hline 7 & 0.511 & 20 & 1.05 & 1.1025 \\
\hline 8 & 0.413 & 18 & -0.95 & 0.9025 \\
\hline 9 & 0.9692 & 24 & 5.05 & 25.5025 \\
\hline 10 & 0.4596 & 18 & -0.95 & 0.9025 \\
\hline 11 & 0.2568 & 12 & -6.95 & 48.3025 \\
\hline 12 & 0.7442 & 24 & 5.05 & 25.5025 \\
\hline 13 & 0.527 & 20 & 1.05 & 1.1025 \\
\hline 14 & 0.557 & 20 & 1.05 & 1.1025 \\
\hline 15 & 0.905 & 24 & 5.05 & 25.5025 \\
\hline 16 & 0.5298 & 20 & 1.05 & 1.1025 \\
\hline 17 & 0.7359 & 24 & 5.05 & 25.5025 \\
\hline 18 & 0.0061 & 1 & -17.95 & 322.2025 \\
\hline 19 & 0.9517 & 24 & 5.05 & 25.5025 \\
\hline 20 & 0.5011 & 20 & 1.05 & 1.1025 \\
\hline & $\mathrm{T} / \mathrm{x}_{\mathrm{med}}$ & 382 & 18.95 & 628.25 \\
\hline \multicolumn{5}{|c|}{$\bar{X}=382 / 20=19.1 ; \sigma^{2}=628.25 / 20=31.41 ; \sigma==5.6 ; \mathrm{Cv}=\sigma / \bar{X}=5.6 / 19.1=0.293 ; \mathrm{T}=2.09$} \\
\hline
\end{tabular}


According to the calculations, the number of registered candidates will vary between 16.48 and 21.71 .

\subsubsection{Gauss distribution}

Calculating the distribution of the analysed series according to the pre-established coefficients of Gauss and the original series is obtained the values from Table 6. They are graphically represented in order to observe the difference between Gauss representation and the real situation for the four analysed years (Figure 2).

Table 6. Comparing the values obtained with the Gauss distribution

\begin{tabular}{|l|c|c|c|c|c|c|c|c|}
\hline \multirow{2}{*}{$\%$} & \multicolumn{4}{|c|}{ Gauss } & \multicolumn{4}{c|}{ Calc } \\
\cline { 2 - 9 } & 2019 & 2018 & 2017 & 2016 & 2019 & 2018 & 2017 & 2016 \\
\hline $0.1 \%$ the weakest & 0 & 0 & 0 & 0 & 0 & 0 & 0 & 0 \\
\hline $2.2 \%$ very weak & 4 & 4 & 4 & 4 & 10 & 12 & 9 & 9 \\
\hline $13.6 \%$ weak & 24 & 23 & 27 & 26 & 21 & 20 & 24 & 38 \\
\hline $68.2 \%$ medium & 122 & 117 & 132 & 129 & 24 & 47 & 90 & 65 \\
\hline $13.6 \%$ good & 24 & 23 & 27 & 26 & 32 & 26 & 15 & 31 \\
\hline $2.2 \%$ very good & 4 & 4 & 4 & 4 & 91 & 66 & 56 & 46 \\
\hline $0.1 \%$ the best & 0 & 0 & 0 & 0 & 0 & 0 & 0 & 0 \\
\hline Total & 178 & 171 & 194 & 189 & 178 & 171 & 194 & 189 \\
\hline
\end{tabular}
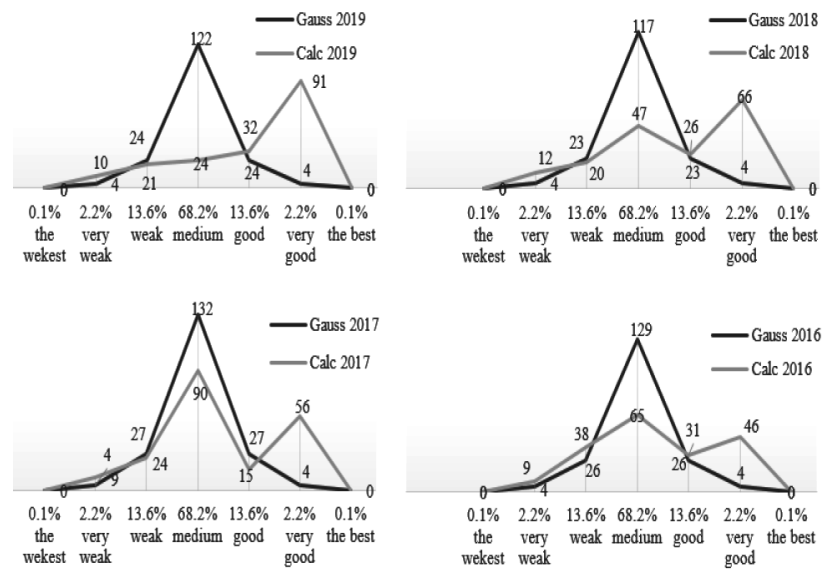

Figure 2. Graphical representation for Gauss and calculated values on years

Analysing the graphics above (according to both sets of data) are observed (Figure 3): In the first graphic, for 2019, compared with the Gauss representation, there are two kurtoses, the smallest is on the left and is very reduced compared to the other four graphics, the highest being on the right, so the skewness is positive and the series is leptokurtic; In the second graphic, for 2018, there are also two kurtoses, in the centre and the right, almost equal, so the series is platykurtic; In the third and the fourth graphic, for 2017 and respectively, 2016, they 
are also two kurtoses, the highest in the centre and the smallest in the right, but high enough, the series being leptokurtic. All the four series are not following a perfect Gauss distribution, but one made in the right and the centre, showing that the highest number of candidates is concentrated in the right, and respectively in the centre (for very good and medium values).

\subsubsection{Markov chains}

All the values per year are presented in Table 7, and then, using stochastic calculations, are transformed into probabilities.

Table 7. Data about enrolled students on years and days

\begin{tabular}{|c|c|c|c|c|c|}
\hline Day/year & 2016 & 2017 & 2018 & 2019 & Totals \\
\hline 1 & 7 & 15 & 4 & 1 & 27 \\
\hline 2 & 10 & 14 & 4 & 1 & 29 \\
\hline 3 & 0 & 22 & 17 & 3 & 42 \\
\hline 4 & 15 & 0 & 11 & 3 & 29 \\
\hline 5 & 11 & 13 & 11 & 5 & 40 \\
\hline 6 & 10 & 14 & 15 & 0 & 39 \\
\hline 7 & 14 & 17 & 7 & 7 & 45 \\
\hline 8 & 13 & 10 & 8 & 23 & 54 \\
\hline 9 & 13 & 14 & 6 & 18 & 51 \\
\hline 10 & 8 & 7 & 8 & 24 & 47 \\
\hline 11 & 2 & 3 & 4 & 14 & 23 \\
\hline 12 & 0 & 10 & 13 & 2 & 25 \\
\hline 13 & 10 & 13 & 16 & 12 & 51 \\
\hline 14 & 16 & 17 & 7 & 12 & 52 \\
\hline 15 & 19 & 12 & 9 & 20 & 60 \\
\hline 16 & 14 & 7 & 18 & 24 & 63 \\
\hline 17 & 27 & 6 & 13 & 9 & 55 \\
\hline Totals & 189 & 194 & 171 & 178 & 732 \\
\hline
\end{tabular}

\begin{tabular}{|c|c|c|c|c|}
\hline 2016 & 2017 & 2018 & 2019 & Percent \\
\hline 0.26 & 0.56 & 0.15 & 0.03 & 1 \\
\hline 0.34 & 0.48 & 0.14 & 0.04 & 1 \\
\hline 0.00 & 0.52 & 0.40 & 0.08 & 1 \\
\hline 0.52 & 0.00 & 0.38 & 0.10 & 1 \\
\hline 0.28 & 0.33 & 0.28 & 0.11 & 1 \\
\hline 0.26 & 0.36 & 0.38 & 0.00 & 1 \\
\hline 0.31 & 0.38 & 0.16 & 0.15 & 1 \\
\hline 0.24 & 0.19 & 0.15 & 0.42 & 1 \\
\hline 0.25 & 0.27 & 0.12 & 0.36 & 1 \\
\hline 0.17 & 0.15 & 0.17 & 0.51 & 1 \\
\hline 0.09 & 0.13 & 0.17 & 0.61 & 1 \\
\hline 0.00 & 0.40 & 0.52 & 0.08 & 1 \\
\hline 0.20 & 0.25 & 0.31 & 0.24 & 1 \\
\hline 0.31 & 0.33 & 0.13 & 0.23 & 1 \\
\hline 0.32 & 0.20 & 0.15 & 0.33 & 1 \\
\hline 0.22 & 0.11 & 0.29 & 0.38 & 1 \\
\hline 0.49 & 0.11 & 0.24 & 0.16 & 1 \\
\hline & & & & \\
\hline
\end{tabular}

From the table above, data are put on four categories, in order to form an equal number of columns and rows to make probability calculations (Table 8). Making the calculations specific to probability, are obtained the numbers from Table 9.

Table 8. Data on years and days

\begin{tabular}{|l|c|c|c|c|c|}
\hline Cumulated day/year & 2016 & 2017 & 2018 & 2019 & Total \\
\hline day $1-4$ & 32 & 51 & 36 & 8 & 127 \\
\hline day $5-8$ & 48 & 54 & 41 & 35 & 178 \\
\hline day $9-13$ & 33 & 47 & 47 & 70 & 197 \\
\hline day $14-17$ & 76 & 42 & 47 & 65 & 230 \\
\hline Total & 189 & 194 & 171 & 178 & 732 \\
\hline
\end{tabular}


Table 9. Probability on days/years

\begin{tabular}{|l|c|c|c|c|}
\hline \multicolumn{1}{|c|}{ Interval/year } & 2016 & 2017 & 2018 & 2019 \\
\hline day $1-4$ & 0.17 & 0.26 & 0.21 & 0.04 \\
\hline day $5-8$ & 0.25 & 0.28 & 0.23 & 0.20 \\
\hline day $9-13$ & 0.18 & 0.24 & 0.28 & 0.39 \\
\hline day $14-17$ & 0.40 & 0.22 & 0.28 & 0.37 \\
\hline Total & 1 & 1 & 1 & 1 \\
\hline
\end{tabular}

By calculating the probability $P_{i}$ of each year in total candidates on analysed years

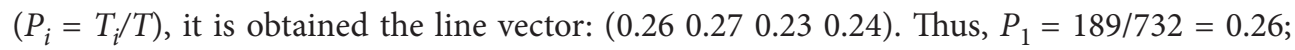
$P_{2}=194 / 732=0.27 ; P_{3}=171 / 732=0.23 ; P_{4}=178 / 732=0.24$. Then, it is made the calculations, according to the Markov chains method (Table 10).

Table 10. Future number of enrolled students using Markov chains

\begin{tabular}{|l|c|c|c|c|c|c|}
\hline $\begin{array}{c}\text { Interval/Forecasted } \\
\text { year }\end{array}$ & 2020 & 2021 & 2022 & 2023 & 2024 & 2025 \\
\hline day 1-4 & 0.26 & 0.25 & 0.26 & 0.24 & 0.25 & 0.25 \\
\hline day 5-8 & 0.25 & 0.26 & 0.26 & 0,26 & 0.25 & 0.25 \\
\hline day 9-13 & 0.25 & 0.24 & 0.24 & 0.26 & 0.25 & 0.25 \\
\hline day 14-17 & 0.24 & 0.25 & 0.24 & 0.24 & 0.25 & 0.25 \\
\hline
\end{tabular}

Putting this data in a graphical representation (Figure 3) could be perceived as a forecasted trend for the future years. Can be observed that: i) for the first period between 1-4 days the forecasted number of enrolled students will follow a decreasing trend for 2021 (0.25) and 2023 (0.24), and after 2024 it will stabilize to 0.25 for a long time; ii) for the second period of enrolment between 5-8 days the trend will be rising for 2021, 2022 and 2023 (0.26), after this from 2024 also tend to stabilize to 0.25 , as the first period; iii) For the third period between 9-13 days the trend is decreasing, having lower values as 0.24 for 2021 and 2022, is increasing for 2023 at 0.26 , then stabilizing at the same values as the first periods at 0.25 for an extended period; iv) for the last analysed period, the trend is entirely stagnated at 0.24 , being the lowest, with a pick of 0.25 in 2021, then stabilizing after 2024 at 0.25 , like all other analysed periods. The value where all four periods may be probably stabilized is 0.25 . Thus the ideal number of enrolled students may run between 180 and 186 (by approximation in minus or plus).

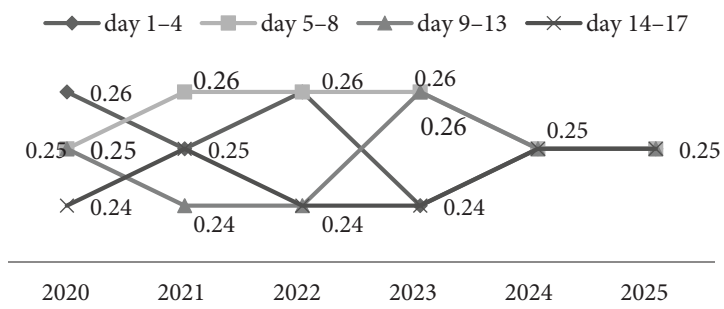

Figure 3. Forecasted number of enrolled students between 2020-2025 
According to the forecasted values per year, measures could be taken from time for the last two periods when the values of enrolled students were the lowest, even if they will be stabilized at the same values as the others, meaning for the periods between 9-13 days and 14-17 days. That means that for the first two periods, in the first eight days, students are coming more to enrol. Thus, a plan for a better enrolment could be implemented in order to diminish this issue. It means that the website information, the mouth-to-mouth methods from professors and students, the new technologies (Facebook, WhatsApp, and telephones), the campaigns taken from the time of the analysed university had results, and the interested persons will come in the first days to enrol.

Based on the results obtained for objective 1, Hypothesis 1 is validated as follows: i) The Monte Carlo method allows the simulation of the future number of enrolled students and the determination of the daily probability, by using the relative frequency obtaining an average interval of the daily enrollments. This can significantly contribute to ensuring the efficiency of the analyzed institution; ii) The Gaussian distribution highlights the difference between Gauss's predetermined coefficients and the real situation for the analyzed period, so the method can be applied to manage student enrolment; iii) Since the prediction of enrollment of future students can be done by the Markov chains method, it is considered that this method can be useful for implementing future university management strategies, which will contribute to improving the relationship with students, from the enrollment stage.

\subsection{Results for Objective 2}

For the product lifecycle cost assessment, it was performed the first two forms of sensitivity analysis. In both one-way sensitivity analysis and multi-directional sensitivity analysis, the parameters whose values were tested were the number of students and the amount of the annual fee (Table 11-13).

Table 11. One-way analysis by the number of students

\begin{tabular}{|l|c|c|c|c|c|c|}
\hline & Year 1 & Year 2 & Year 3 & Year 4 & Year 5 & $\begin{array}{c}\text { Total per } \\
\text { life cycle }\end{array}$ \\
\hline \multicolumn{7}{|c|}{ Variant 1 } \\
\hline Number of students & 50 & 100 & 200 & 100 & 50 & 500 \\
\hline Annual student/study fee (Eur) & 638 & 638 & 745 & 745 & 638 & - \\
\hline $\begin{array}{l}\text { Total receipts from tuition fees } \\
\text { (Eur) }\end{array}$ & 31,915 & 63,830 & 148,936 & 74,468 & 31,915 & 351,064 \\
\hline Annual income (Eur) & $-27,452$ & 9,851 & 94,626 & 20,702 & $-25,889$ & 71,839 \\
\hline \multicolumn{7}{|c|}{ Variant 2 } \\
\hline Number of students & 45 & 75 & 175 & 75 & 30 & 400 \\
\hline Annual student/study fee (Eur) & 638 & 638 & 745 & 745 & 638 & - \\
\hline $\begin{array}{l}\text { Total receipts from tuition fees } \\
\text { (Eur) }\end{array}$ & 28,723 & 47,872 & 130,319 & 55,851 & 19,149 & 281,915 \\
\hline Annual income (Eur) & $-30,644$ & $-6,106$ & 76,009 & 2,085 & $-38,654$ & 2,690 \\
\hline
\end{tabular}


End of Table 11

\begin{tabular}{|l|c|c|c|c|c|c|}
\hline & Year 1 & Year 2 & Year 3 & Year 4 & Year 5 & $\begin{array}{c}\text { Total per } \\
\text { life cycle }\end{array}$ \\
\hline \multicolumn{7}{|c|}{ Variant 3 } \\
\hline Number of students & 40 & 85 & 180 & 50 & 20 & 375 \\
\hline Annual student/study fee (Eur) & 638 & 638 & 745 & 745 & 638 & - \\
\hline $\begin{array}{l}\text { Total receipts from tuition fees } \\
\text { (Eur) }\end{array}$ & 25,532 & 54,255 & 134,043 & 37,234 & 12,766 & 263,830 \\
\hline Annual income (Eur) & $-33,835$ & 277 & 79,732 & $-16,532$ & $-45,037$ & $-15,395$ \\
\hline
\end{tabular}

Table 12. Sensitivity analysis according to the value of the annual fee - one-way analysis

\begin{tabular}{|l|c|c|c|c|c|c|}
\hline & Year 1 & Year 2 & Year 3 & Year 4 & Year 5 & $\begin{array}{c}\text { Total per } \\
\text { life cycle }\end{array}$ \\
\hline \multicolumn{7}{|c|}{ Variant 1 } \\
\hline Number of students & 50 & 50 & 50 & 50 & 50 & 250 \\
\hline Annual student/study fee (Eur) & 745 & 745 & 745 & 745 & 745 & - \\
\hline $\begin{array}{l}\text { Total receipts from tuition fees } \\
\text { (Eur) }\end{array}$ & 37,234 & 37,234 & 37,234 & 37,234 & 37,234 & 186,170 \\
\hline Annual income (Eur) & $-22,133$ & $-16,744$ & $-17,077$ & $-16,532$ & $-20,569$ & $-93,055$ \\
\hline \multicolumn{7}{|c|}{ Variant 2 } \\
\hline Number of students & 50 & 50 & 50 & 50 & 50 & 250 \\
\hline Annual student/study fee (Eur) & 851 & 851 & 851 & 851 & 851 & - \\
\hline $\begin{array}{l}\text { Total receipts from tuition fees } \\
\text { (Eur) }\end{array}$ & 42,553 & 42,553 & 42,553 & 42,553 & 42,553 & 170,213 \\
\hline Annual income (Eur) & $-16,814$ & $-11,425$ & $-11,757$ & $-11,213$ & $-15,250$ & $-66,459$ \\
\hline \multicolumn{7}{|c|}{ Variant 3 } \\
\hline Number of students & 50 & 50 & 50 & 50 & 50 & 250 \\
\hline Annual student/study fee (Eur) & 1,064 & 1,064 & 1,064 & 1,064 & 1,064 & - \\
\hline $\begin{array}{l}\text { Total receipts from tuition fees } \\
\text { (Eur) }\end{array}$ & 53,191 & 53,191 & 53,191 & 53,191 & 53,191 & 265,957 \\
\hline Annual income (Eur) & $-6,176$ & -787 & $-1,119$ & -574 & $-4,612$ & $-13,268$ \\
\hline
\end{tabular}

From the sensitivity analysis of the LCC method model we can draw the following conclusions: for a constant number of 50 students annually it is impossible to reach the break-even point, the licensed program being ineffective for fee values between $€ 638$ and $€ 1,064$; in the variant of attracting a maximum number of students for each year of study, profitability can be obtained from year 2 of the program to year 4; in the case of average values of the number of students generated from the analysis of other master programs, the master program is profitable in years 2 and 3, and its overall profitability is achieved. However, the same result cannot be achieved in the variant of a total number of students over the life cycle below the minimum allowable values of the average break-even threshold (438 students). 
Table 13. Sensitivity analysis by the number of students and the amount of annual fee - multi-directional analysis

\begin{tabular}{|l|c|c|c|c|c|c|}
\hline & Year 1 & Year 2 & Year 3 & Year 4 & Year 5 & $\begin{array}{c}\text { Total per } \\
\text { life cycle }\end{array}$ \\
\hline \multicolumn{7}{|c|}{ Variant 1 } \\
\hline Number of students & 50 & 50 & 200 & 100 & 50 & 450 \\
\hline Annual student/study fee (Eur) & 638 & 745 & 745 & 745 & 745 & \\
\hline Total receipts from tuition fees (Eur) & 31,915 & 37,234 & 148,936 & 74,468 & 37,234 & 329,787 \\
\hline Annual income (Eur) & $-27,452$ & $-16,744$ & 94,626 & 20,702 & $-20,569$ & 50,562 \\
\hline \multicolumn{7}{|c|}{ Variant 2 } \\
\hline Number of students & 45 & 45 & 175 & 75 & 30 & 370 \\
\hline Annual student/study fee (Eur) & 851 & 851 & 957 & 851 & 851 & \\
\hline Total receipts from tuition fees (Eur) & 38,298 & 38,298 & 167,553 & 63,830 & 25,532 & 333,511 \\
\hline Annual income (Eur) & $-21,069$ & $-15,680$ & 113,243 & 10,064 & $-32,271$ & 54,286 \\
\hline \multicolumn{7}{|c|}{ Variant 3 } \\
\hline Number of students & 40 & 45 & 150 & 40 & 20 & 295 \\
\hline Annual student/study fee (Eur) & 638 & 745 & 851 & 745 & 638 & \\
\hline Total receipts from tuition fees (Eur) & 25,532 & 33,511 & 127,660 & 29,787 & 12,766 & 229,255 \\
\hline Annual income (Eur) & $-33,835$ & $-20,468$ & 73,349 & $-23,979$ & $-45,037$ & $-49,970$ \\
\hline
\end{tabular}

Based on the results provided by the multi-directional analysis it can be concluded that a positive return on the overall life cycle study program can be achieved in the context of the annual increase in both the number of students and the tuition fee. Another tool offered by econometric modelling is the analysis of correlations between variables (Table 14). There is a strong inverse correlation between $\mathrm{R} \& \mathrm{D}$ and operational cost variables, as well as between $\mathrm{R} \& \mathrm{D}$ and closing costs.

Table 14. Analysis of correlations between variables

\begin{tabular}{|l|l|c|c|c|}
\hline \multicolumn{2}{|l|}{} & Total service costs & Operational costs & Withdrawal costs \\
\hline \multirow{5}{*}{ Total service costs } & $\begin{array}{l}\text { Pearson } \\
\text { Correlation }\end{array}$ & 1 & 0.570 & -0.671 \\
\cline { 2 - 5 } & Sig. (2-tailed) & & 0.315 & 0.215 \\
\cline { 2 - 5 } Operational costs & $\mathrm{N}$ & 5 & 5 & 5 \\
\hline \multirow{5}{*}{ Withdrawal costs } & $\begin{array}{l}\text { Pearson } \\
\text { Correlation }\end{array}$ & 0.570 & 1 & -0.878 \\
\cline { 2 - 5 } & Sig. (2-tailed) & 0.315 & 5 & 0.050 \\
\cline { 2 - 5 } & $\mathrm{N}$ & 5 & -0.878 & 1 \\
\cline { 2 - 5 } & $\begin{array}{l}\text { Pearson } \\
\text { Correlation }\end{array}$ & -0.671 & 0.050 & 5 \\
\cline { 2 - 5 } & Sig. (2-tailed) & 0.215 & 5 & \\
\hline
\end{tabular}


The linear regression method studies the link between the LCC cost dependent variable and several independent variables associated with the various stages of the study program's life cycle - R\&D costs, operational costs, and support costs and withdrawal costs. Independent variables have been chosen as the main cost elements, components of the LCC method, which define its structure. The cost values associated with the LCC method were previously calculated and are presented in Table 15, and used cost values at the level of 2019.

Table 15. Variables of linear regression equations

\begin{tabular}{|c|c|c|c|c|}
\hline $\begin{array}{c}\text { V1 } \\
\text { R\&D costs }\end{array}$ & $\begin{array}{c}\text { V2 } \\
\text { Total Service Costs }\end{array}$ & $\begin{array}{c}\text { V3 } \\
\text { Operational costs }\end{array}$ & $\begin{array}{c}\text { V4 } \\
\text { Withdrawal costs }\end{array}$ & $\begin{array}{c}\text { V5 } \\
\text { LC Associated } \\
\text { Cost }\end{array}$ \\
\hline 5,771 & 1,809 & 51,787 & 0 & 59,367 \\
\hline 1,319 & 979 & 51,681 & 0 & 53,978 \\
\hline 1,332 & 1,617 & 51,362 & 0 & 54,311 \\
\hline 1,340 & 1,489 & 50,936 & 0 & 53,766 \\
\hline 1,346 & 851 & 50,085 & 5,521 & 57,803 \\
\hline
\end{tabular}

The general form of the simple regression equation is $Y=c(1)+c(2) \times X, X$ defining the independent variable and $Y$ defining the dependent variable. The probability associated with parameters $c(1)$ and $c(2)$, (which can take values between 0 and 1 ) gives the measure of the significance of the parameters generated (obtained from the generation of the regression equation), i.e., the closer the value obtained is closer to 0 , the higher the significance of the parameter. If the probability value is close to 1 , by studying the results of the t-test or student test, the insignificance of the parameter can be concluded.

In order to interpret the results presented above, related to simple regression equations, it is necessary to define the main elements generated by the modelling program theoretically. Based on the estimates of the regression parameters for the proposed equations obtained using the SPSS program (Supplementary Material, Annexes 1-4), the information in Table 16 was obtained.

By observing the data in Table 16, it can be concluded that there is a high significance of the parameters for Model 1 and Model 4, while Model 2 and 3 have low meanings of the parameters. In the case of the first model, R-square $=0.591$ means that $59.10 \%$ of the variance of variable $y$ can be explained using the regression equation, the difference up to $100 \%$ not explained. In the case of the second econometric model, R-square $=0.022$ means that $2.20 \%$ of the variance of the dependent variable is explained by the econometric model, which allows us to conclude that this model is less relevant than the first. For the third and fourth equations, the values of R-squared are 0.01 and 0.1815 , so $1.01 \%$ in the case of model three and $18.15 \%$ in the case of the model appeared from the variance of the dependent variable is explained by the chosen model. The decreasing order of relevance of the chosen models is, therefore, Model 1, Model 3, Model 4, and Model 2. Thus, we can conclude that the value of the cost of the LCC is strongly dependent on the value of the R\&D costs as well as the operational ones, with the total and closing costs having a lower impact. The t-test is utilized to test the statistical significance of the linear relationship between the two variables 


\begin{tabular}{|c|c|c|c|c|}
\hline $\begin{array}{l}\widehat{ত} \\
u \\
0 \\
0 \\
0\end{array}$ & $\begin{array}{l}\stackrel{\text { Iे }}{0} \\
\text { : }\end{array}$ & $\begin{array}{l}\exists \\
\vec{\infty} \\
0 \\
0\end{array}$ & $\begin{array}{c}\mathbb{N} \\
\infty \\
0 \\
0\end{array}$ & 站 \\
\hline 을 & $\begin{array}{ll}0 & \\
⿱ 亠 䒑 & \overrightarrow{8} \\
\delta & 0 \\
0 & 0 \\
0 & 0 \\
0 & v\end{array}$ & $\begin{array}{l}\text { İ } \\
\stackrel{0}{0}\end{array}$ & $\begin{array}{l}\text { H } \\
\text { ஸn }\end{array}$ & 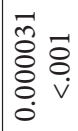 \\
\hline 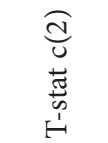 & $\begin{array}{l}0 \\
\stackrel{\infty}{0} \\
i\end{array}$ & $\begin{array}{l}\text { ì } \\
\text { ָ̦ }\end{array}$ & $\frac{n}{\stackrel{1}{1}}$ & $\begin{array}{l}\text { बे } \\
10 \\
\infty \\
0 \\
0\end{array}$ \\
\hline 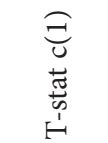 & 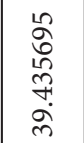 & $\stackrel{\substack{\tilde{O} \\
ٍ}}{=}$ & $\begin{array}{l}\stackrel{0}{0} \\
0 \\
0 \\
0\end{array}$ & $\begin{array}{l}\stackrel{n}{\sim} \\
\stackrel{F}{F}\end{array}$ \\
\hline 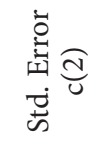 & \begin{tabular}{l}
$\stackrel{1}{\pi}$ \\
$\infty$ \\
\multirow{F}{*}{} \\
$\stackrel{0}{0}$
\end{tabular} & $\begin{array}{l}\hat{n} \\
\hat{n} \\
n\end{array}$ & $\stackrel{m}{\stackrel{n}{i}}$ & 年 \\
\hline 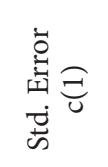 & $\begin{array}{l}0 \\
0 \\
0 \\
0 \\
0 \\
0 \\
\dot{0} \\
0 \\
0\end{array}$ & 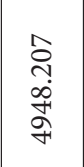 & $\begin{array}{l}\text { \&ै } \\
\text { ñ. } \\
\hat{0} \\
\text { ô } \\
0\end{array}$ & 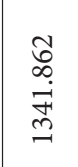 \\
\hline 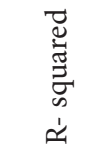 & $\begin{array}{l}\bar{\sigma} \\
\hat{n} \\
0\end{array}$ & $\begin{array}{l}\text { तै } \\
0 \\
0\end{array}$ & $\ddot{\circ}$ & $\begin{array}{l}\frac{10}{0} \\
\stackrel{\infty}{+} \\
0\end{array}$ \\
\hline 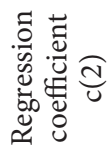 & $\begin{array}{l}\stackrel{+}{\infty} \\
\text { ఫे } \\
\text { ळ. }\end{array}$ & $\begin{array}{l}\stackrel{0}{O} \\
\Xi \\
\text { ลे } \\
\vdots\end{array}$ & $\begin{array}{l}m \\
\stackrel{n}{0} \\
\stackrel{p}{1}\end{array}$ & $\stackrel{?}{\stackrel{f}{*}}$ \\
\hline 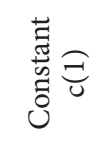 & 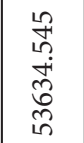 & $\begin{array}{l}\text { ఫे } \\
\text { i } \\
\text { ర్t } \\
\text { in }\end{array}$ & 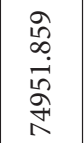 & $\begin{array}{l}8 \\
10 \\
10 \\
n \\
n \\
n \\
n\end{array}$ \\
\hline 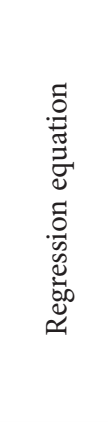 & 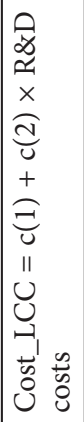 & 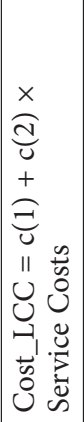 & 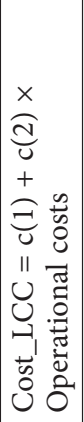 & 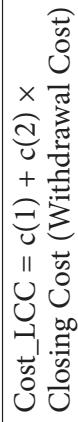 \\
\hline
\end{tabular}


of a model or equations. A value of probability $\mathrm{p}$ associated with the low t-test means that there is a significant link between the two variables. For the regression equations analysed we have the following values of east $\mathrm{t}$ : Equation 1: $t=2.080$ with 3 degrees of freedom and associated probability $p=0.129$; Equation 2 : $t=0.260$ with 3 degrees of freedom and associated probability $p=0.811$; Equation $3: t=0.175$ with 3 degrees of freedom and associated probability $p=0.872$; Equation $4: t=0.815$ with 3 degrees of freedom and associated probability $p=0.474$. It can also be observed in this analysis the increased significance of models 1 and 4 compared to the other two models. Once again, the strong influence of R\&D and operational costs in determining the cost associated with the life cycle compared to the closing costs or baskets of service is highlighted.

Based on the results obtained for objective 2, Hypothesis 2 is validated as follows: i) the sensitivity analysis of the LCC method highlights the positive profitability of the study program throughout the life cycle resulting in the context of the annual increase in both the number of students and the tuition fee or in the case of values averages of the number of students the study program is profitable in years 2 and 3; ii) The LCC allows the identification of those cost areas or areas that require higher growth or deeper control in order to maintain them at specific rates or to reduce them, where possible; iii) the statistical methods applied highlight the strong influence of research and development costs and operational costs in determining the cost associated with the life cycle compared to closure costs.

\section{Conclusions}

The education market is dynamic and continuously changing, and economic-social factors and internationalization require universities to rethink their missions and have greater flexibility concerning today's developments. Universities need to restructure their curricula so that they quickly meet labour market requirements. To attract more valuable students and maintain them, the institution could follow the steps developed above and use the Monte Carlo simulation in order to determine possible future problems and to determine the right number of necessary students, which may ensure the future performance of the university. As it is observed, the simulation method used above helps the institution to determine the future risks and to predict when and what relationship marketing programs to use in order to attract, maintain and grow the number of valuable students.

The introduction of a new study program should start from a thorough analysis of market requirements, customer characteristics, and competitors' offers, which often makes the price at which it can be offered on the Market. Furthermore, an analysis of the profitability of a new study program is not complete and relevant if it does not cover the entire life cycle of the program, thus it is essential to include the LCC method in the analysis. One of the main problems in reaching and maintaining a specific rate of profitability is estimating the majority of costs in the initial phase, and managing them in the growth phase and after the time of their appearance. The main problem with cost management is thus the failure to include all costs over the life cycle of the services at the time of the initial estimate. Thus, there is a 
high risk that there will be a cost of study programs that are not accurately estimated, and that is not properly managed in terms of strategic management. In this context, the financial target at a university should aim to maximize income while maintaining or even reducing expenditure. The solution of creating their funding resources and avoiding dependence on a single funder seem to be fundamental needs. The calculation of standard costs per student could also ensure the economic basis of the fees charged for university services. At the same time, creating an organizational culture based on saving could ensure financial performance. Also, as a research limitation, it is considered that the application of LCC requires considerable resources of time and the data necessary for its application may be challenging to obtain or that its accuracy may suffer due to uncertainties that may arise in the future.

Universities, both state and private, need to be aware of the inadequacy of the funding from study fees and must become much more cautious in calculating costs. Often, management structures, as well as students, need detailed justification of how funds are managed. As a result, the accounting tool is best suited to highlight the costs associated with the educational process, only thus succeeding in calibrating tuition fees, which meet both the expectations of potential students and the need for survival and/or institutional prosperity.

The paper contributes to the development of scientific literature in the field of university management and managerial accounting, by the fact that the study proposes a reorganization of the management of universities by making calculations on the viability of developing new undergraduate study programs throughout their life cycle. The research limitation results from the fact that the proposed model is implemented only on a single license program. It is obvious that each university program (bachelor, master, doctorate) has its own requirements (number of teachers, university infrastructure, methodological requirements, number of students, etc.) that must be analyzed separately. The model can be extended to other university study programs, so as to contribute sustainably to increasing university performance and cost management. As a future research direction, it can be considered, the application of the bidirectional model on other university specializations, which have different characteristics for the study programs and different student admissions.

\section{Funding}

This research received no external funding.

\section{Author contributions}

All the authors contributed equally to the elaboration of this research.

\section{Disclosure statement}

The authors declare no conflict of interest. 


\section{References}

Ackerman, R., \& Schibrowsky, J. (2007). A business marketing strategy applied to student retention: A higher education initiative. Journal of College Student Retention: Research, Theory \& Practice, 9(3), 307-336. https://doi.org/10.2190/CS.9.3.d

Altbach, P. G., Reisberg, L., \& Rumbley, L. E. (2009). Trends in global higher education: Tracking an academic revolution. A report prepared for the UNESCO 2009 World Conference on Higher Education. Published with support from SIDA/SAREC. http://www.cep.edu.rs/public/Altbach,_Reisberg,_Rumbley_Tracking_an_Academic_Revolution,_UNESCO_2009.pdf

Ashworth, A. (1993). How lifecycle costs could have improved existing costing. In J. W. Bull (Ed.), Life cycle costing for construction. Blackie Academic and Professional.

Asiedu, Y., \& Gu, P. (1998). Product life cycle cost analysis: State of the art review. International Journal of Production Research, 36(4), 883-908. https://doi.org/10.1080/002075498193444

Balzer, W. K. (2020). Lean higher education: Increasing the value and performance of university processes ( $2^{\text {nd }}$ ed.). Routledge. https://doi.org/10.4324/9781351216944

Baran, R. J., Galka, R. J., \& Strunk, D. P. (2008). Principles of customer relationship management. Thomson South-Western.

Beardwell, J., \& Claydon, T. (2007). Human resource management: A contemporary approach (5 ${ }^{\text {th }}$ ed.). Pearson Education. http://www.microlinkcolleges.net/elib/files/undergraduate/AccountingandFinance/Human\%20Resource\%20Management,\%20A\%20Contemporary\%20Approach,\%205th\%20 Edition.pdf

Brock, R. (2019). Young adult literature in action: A librarian's guide ( $3^{\text {rd }}$ ed.). ABC-CLIO.

Brown, R. J., \& Yanuck, R. R. (1980). Life-cycle costing: A practical guide for energy managers. Fairmont Press. https://www.amazon.com/Life-Cycle-Costing-Practical-Managers/dp/0915586177

Chaminade, C., \& Lundvall, B.-Å. (2019). Science, technology, and innovation policy: Old patterns and new challenges. In Oxford research encyclopedia of business and management. https://doi.org/10.1093/acrefore/9780190224851.013.179

Chen, I. J., \& Popovich, K. (2003). Understanding customer relationship management (CRM): People, process and technology. Business Process Management Journal, 9(5), 672-688. https://doi.org/10.1108/14637150310496758

Ching, W., Huang, X., Ng, M., \& Siu, T. (2013). Markov chains: Models, algorithms and applications. Springer Science \& Business Media. https://doi.org/10.1007/978-1-4614-6312-2

Dall'Alba, G., \& Barnacle, R. (2007). An ontological turn for higher education. Studies in Higher Education, 32(6), 679-691. https://doi.org/10.1080/03075070701685130

Dhillon, B. (2009). Life cycle costing for engineers ( $1^{\text {st }}$ ed.). CRC Press. https://doi.org/10.1201/9781439816899

Duica, A., \& Florea, N. V. (2018). Challenges for business- E-recruitment and modeling. The Journal Contemporary Economy, 3(3), 19-29. https://ideas.repec.org/a/brc/brccej/v3y2018i3p19-29.html

Duica, M. C., Florea, N. V., Duica, A., \& Gilmeanu, R. (2019). Improving the relationships between organizations and their customers using digital multichannel communication and mathematical simulation. Economic Computation \& Economic Cybernetics Studies \& Research, 53(1), 265-280. https://doi.org/10.24818/18423264/53.1.19.17

Emblemsvåg, J. (2003). Life-cycle costing: Using activity-based costing and Monte Carlo methods to manage future costs and risks. John Wiley \& Sons.

Evans, G. R., \& Gill, J. (2017). Universities and students: A guide to rights, responsibilities and practical remedies ( $1^{\text {st }}$ ed.). Routledge. https://doi.org/10.4324/9781315042503 
Florea, N. V., \& Mihai, D. C. (2017). Predicting employees' evaluation performance using simulation and mathematical modeling. Journal of Science and Arts, 17(1), 81.

Foglieni, F., Villari, B., \& Maffei, S. (2017). Designing better services: A strategic approach from design to evaluation. Springer. https://doi.org/10.1007/978-3-319-63179-0

Fukuda, S. (2017). Emotional engineering (Vol. 5). Springer International Publishing. https://doi.org/10.1007/978-3-319-53195-3

Gluch, P., \& Baumann, H. (2004). The life cycle costing (LCC) approach: A conceptual discussion of its usefulness for environmental decision-making. Building and Environment, 39(5), 571-580. https://doi.org/10.1016/j.buildenv.2003.10.008

Harland, T. (2012). University teaching: An introductory guide ( $1^{\text {st }}$ ed.). Routledge. https://doi.org/10.4324/9780203120606

Ianos, I. (2010). Insertia teritoriala a universitatilor din Romania. Editura Universitara.

Kahn, P., \& Anderson, L. (2019). Developing Your teaching: Towards excellence (2 ${ }^{\text {nd }}$ ed.). Routledge. https://doi.org/10.4324/9780429490583

Karim, K. E. (2006). Accounting for decision making and control. Issues in Accounting Education, 21(3), 333.

Kaur, K. (2009). Marketing the academic library on the web. Library Management, 30(6-7), 454-468. https://doi.org/10.1108/01435120910982140

Kolomytseva, O., \& Pavlovska, A. (2020). The role of universities in the national innovation system. Baltic Journal of Economic Studies, 6(1), 51-58. https://doi.org/10.30525/2256-0742/2020-6-1-51-58

Lamb, H., Hair, J., McDaniel, C., Faria A. J., \& Wellington, W. J. (2012). Marketing (5 $5^{\text {th }}$ ed.). Nelson Education.

Lechtchinskaia, L., Friedrich, I., \& Breitner, M. H. (2012). Requirements analysis for a student relationship management system - Results from an empirical study in Ivy League universities. In Proceedings of the Annual Hawaii International Conference on System Sciences (pp. 5132-5141). Maui, HI, USA. IEEE. https://doi.org/10.1109/HICSS.2012.502

Linger, H., Fisher, J., Wojtkowski, W., Wojtkowski, W. G., Zupančič, J., Vigo, K., \& Arnold, J. (2004). Constructing the infrastructure for the knowledge economy: Methods and tools, theory and practice. Springer Science \& Business Media. https://doi.org/10.1007/978-1-4757-4852-9

Luban, F. (2005). Business simulations [Simulări in afaceri] Editura ASE.

Nastase (Bidireanu), A., Comandaru, A.-M., Geanina Stanescu, S., Peichea, M., Coman, M. D., \& Ionescu, C. A. (2019). Statistical prediction using to forecast the theory of Markov chains. Journal of Science and Arts, 19(2), 415-424.

Nejati, M. (2013). Frontiers of business, management and economics: An interdisciplinary collection of managerial research findings and breakthroughs. Universal-Publishers.

Ong, D. (2009). The international students' handbook: Living and studying in Australia. UNSW Press.

Oplatka, I., \& Hemsley-Brown, J. (Eds.). (2012). The management and leadership of educational marketing: Research, practice and applications (Vol. 15). Emerald Group Publishing Limited.

Palmatier, R., \& Steinhoff, L. (2019). Relationship marketing in the digital age. Routledge.

Peppers, D., \& Rogers, M. (2004). Managing customer relationships: A strategic framework. John Wiley \& Sons.

Perna, A., \& Baraldi, E. (2014). CRM Systems in industrial companies: Intra-and inter-organizational effects. Palgrave Macmillan.

Pringle, J., \& Fritz, S. (2019). The university brand and social media: Using data analytics to assess brand authenticity. Journal of Marketing for Higher Education, 29(1), 19-44.

https://doi.org/10.1080/08841241.2018.1486345 
Reichert, S. (2019). The role of universities in regional innovation ecosystems. https://eua.eu/resources/ publications/819:the-role-of-universities-in-regional-innovation-ecosystems.html

Sauro, J. (2015). Customer analytics for dummies. John Wiley \& Sons.

Schneider, M., \& Deane, K. C. (Eds.). (2015). The university next door: What is a comprehensive university, who does it educate, and can it survive? Teachers College Press.

Sheldon, S., \& Turner-Vorbeck, T. (Eds.). (2019). The Wiley handbook of family, school, and community relationships in education. John Wiley \& Sons. https://doi.org/10.1002/9781119083054

Spickova, M., \& Myskova, R. (2015). Costs efficiency evaluation using life cycle costing as strategic method. Procedia Economics and Finance, 34, 337-343. https://doi.org/10.1016/S2212-5671(15)01638-X

Sultan, P., \& Wong, H. Y. (2019). How service quality affects university brand performance, university brand image and behavioural intention: the mediating effects of satisfaction and trust and moderating roles of gender and study mode. Journal of Brand Management, 26(3), 332-347. https://doi.org/10.1057/s41262-018-0131-3

Svend, H., \& Oliver, O. (2019). Marketing: A relationship perspective ( $2^{\text {nd }}$ ed.). World Scientific.

Toma, J. (2011). Managing the entrepreneurial university: Legal issues and commercial realities. Routledge. https://doi.org/10.4324/9780203831236

Tracey, W. R. (2004). The human resources glossary: The complete desk reference for HR executives, managers, and practitioners ( $3^{\text {rd }}$ ed.). CRC Press.

Valdani, E., \& Arbore, A. (2013). Bocconi on Management Series: Competitive strategies: Managing the present, imagining the future. Palgrave Macmillan. https://doi.org/10.1057/9780230354586

Williams, P. (2019). Does competency-based education with blockchain signal a new mission for universities? Journal of Higher Education Policy and Management, 41(1), 104-117. https://doi.org/10.1080/1360080X.2018.1520491

Winer, R. S. (2001). A framework for customer relationship management. California Management Review, 43(4), 89-105. https://doi.org/10.2307/41166102

Zio, E. (2013). Springer Series in Reliability Engineering. The Monte Carlo Simulation Method for system reliability and risk analysis. Springer. https://doi.org/10.1007/978-1-4471-4588-2 